\title{
Culture wars, revanchism, moral panics and the creative city. A reconstruction of a decline of tolerant public policy: the case of Dutch anti-squatting legislation. ${ }^{1}$
}

Submitted for publication in Urban Studies.

(Pruijt, Hans (2013) Culture Wars, Revanchism, Moral Panics and the Creative City. A Reconstruction of a Decline of Tolerant Public Policy: The Case of Dutch Anti-squatting Legislation. Urban Studies, 50(6), 1114-1129, doi: 10.1177/0042098012460732 )

abstract

Squatting became illegal in the Netherlands on October 1, 2010. The paper examines the dynamics involved. Theoretically drawing on debates about culture wars, revanchism, moral panics and the creative city, it is based on participant observation in squatter meetings, debates with politicians, a parliament hearing, lobbying meetings and various informal encounters, on a survey $(N=2077)$ and on a collection of documents. A key mechanism that the paper explores is the following. Strategies of resistance that seem more or less manageable in the local context of a creative city can, when they backfire, cause a moral panic on the national level. This provides ammunition for revanchist politicians.

Tolerant public policy can be vulnerable, even when it seems firmly entrenched and based on a long tradition. A case in point is public policy towards squatting in the Netherlands, that various authors have used as an example demonstrating Dutch tolerance (Zahn, 1993, p. 393; Soja, 2000; Maussen and Bogers, 2010).

The passing of anti-squatter legislation by the Dutch Senate in June 2010 is a clear case of a decline of tolerant public policy, and a shift towards increased criminalization. This happened after 45 years of relatively undisturbed urban squatting in the Netherlands, undisturbed at least by legal measures. The 2010 legislation turned squatting into a criminal offense that carries a maximum prison sentence of one year, or two years and eight months if squatters use violence

\footnotetext{
${ }^{1}$ I would like to thank Jeroen van der Waal and two Urban Studies reviewers for their valuable suggestions.
} 
or threaten to use it. Previously, squatting a building that had been vacant for more than one year had not been punishable.

This paper follows the strategy of using divergent theoretical perspectives to explain a single case (Yin, 2009). It presents an analysis of the dynamics involved in the case of the Dutch antisquatting legislation, while making use of four perspectives chosen because they represent very different ways to look at the issue of tolerance: culture wars, revanchism, moral panics and the creative city. In the creative cities literature, tolerance is a competitive advantage. The central assertion is that successful post-industrial cities exhibit a high level of tolerance for diversity. There is a two-way relationship between the influx of the so called creative class and a tolerant cultural climate (Florida, 2002). Under the assumption that governments are inclined to seek competitive advantage, we could say that this perspective focuses on factors that can drive tolerance upwards or at least stabilize it.

In contrast, Revanchism emphasizes a mechanism that entails a decline of tolerance. It denotes a pervasive reaction among citizens and urban decision makers against what they see as a lack of order caused by leftist sixties-style tolerance (Smith, 1996, pp. 44-45).

The moral panic describes a scenario in which one or more incidents enable the construction of a menacing reality in the media. This construction subsequently prompts political interventions in the direction of increased repression (Hall et al., 1978; McRobbie and Thornton, 1995).

A further theoretical angle, culture wars, is about the central idea that in new politics, the main fault lines are no longer along the economic dimension, and that the more important fault lines are now in the cultural dimension (Sharp, 1999). This suggests that we are more likely to see an intensification of conflicts or schisms about values rather than about the distribution of wealth. Conflicts about values generally develop between people who welcome or at least tolerate certain lifestyles or behaviors and people who reject these.

The paper compares the fruitfulness of each approach to explain the case. To a large extent, it is the result of participant observation. From 2003 until 2010 I regularly participated in meetings of the Landelijk Overleg Kraakgroepen (National Council of Squatting Groups) as well as in citywide squatter meetings in Rotterdam and meetings of the groups that planned campaigns against the proposed legislation. I was invited to participate in various debates with squatters, politicians, sometimes including representatives of the police, which allowed me to get to know the protagonists. In the role of an expert I was invited to a meeting with civil servants and activists on possible avenues for public policy regarding the problem of empty buildings, and to provide input to the Standing Committee for Justice of Parliament. These formal occasions led informal encounters. Purely as an observer I was present at a lobbying 
effort. A survey $(\mathrm{N}=2077)^{1}$ was conducted among a representative sample of the Dutch population, and documents were analyzed.

Because tolerance is a variegated concept, some conceptual clarification is necessary. Following the conceptualization offered by Kearns and Bannister (2009), tolerant public policy entails that policy makers assess a given object, which can be a conduct, lifestyle, culture of belief, social group or impact as negative, but choose to respond in a way that does not amount to getting rid of it. This can take the shape of either pure tolerance, i.e. static disapproval plus nonintervention, or some form of dynamic response (Kearns and Bannister, 2009; Bannister and Kearns, 2009). A specific dynamic response that used to apply to squatting in the Netherlands is specifying conditions in advance under which there will be no punishment (Maussen and Bogers, 2010). In Dutch, it is called 'gedogen', which Gordijn (2001) translates as pragmatic tolerance. In the case of squatting in the Netherlands, from 1994 to 2010 the condition under which it was specified that there would be no punishment was that the building had to have been empty for more than one year. The thrust of the 2010 legislation was to change this into zero-tolerance.

The presentation of the case study material below is organized according to the respective theoretical perspective that seems appropriate.

\section{Revanchism}

The concept of revanchism, as proposed by Smith (1996), denotes a revengeful sentiment that drives intolerant policies aimed against people seen as deviants. The sentiment is fuelled by a rejection of earlier tolerant policies that are blamed for allowing deviants to degrade the city. Revanchism manifests itself in campaigns to remove certain categories of people from the city or parts of the city. Davis (1992) described how the municipality of Los Angeles decided to clear the public space from 'undesirables' such a homeless people by a combination of architectural means and stepped-up policing. Smith (1998) mentions a military-style campaign to evict squatters in New York, started by the Giuliani administration, as an example of such a change of political attitude. The broader context can in one word be summarized as neoliberalism. It is commonly associated with a retreat of the state, but Peck and Tickell (2002) convincingly argue that retreat of the state is followed by a phase of proactive interventions motivated by neoliberal ideology.

Confirming this analysis, the case of Dutch anti-squatting legislation can indeed to some extent be interpreted as revanchism. The anti-squatters law is an attack on a phenomenon that originated in the 1960s. The new law also has characteristics of an effort to reverse a 
development, because it can be seen as an attempt to de-institutionalize squatting. Squatting ('Kraken', which means to crack or break into) in the Netherlands is partially institutionalized. This partial institutionalization has several aspects. Squatting is a widely known and understood activity and accepted by a sizeable part of the population, as will be shown further below. It is connected to norms of behavior that set it apart from burglary and vandalism, and the mechanics of squatting are explained in squatters' manuals. Before 2010, under certain conditions, squatting was not a criminal offense. This gave rise to a routine, applied in many cases, in which squatters invited the police to come and check that their occupation met the conditions for not constituting a criminal offense. Until 1994, the main condition was that the building had to be not in use in any way, after a change in law in 1994 the condition was that the building, at the moment of squatting, had to be empty for at least one year. Inviting the police was a way for the squatters to minimize the risk of an eviction based on a criminal charge. For the police it was convenient because it saved them the trouble of taking the reports of those owners who could not expect to obtain an eviction based on criminal charges against the squatters anyway, and would have to start a civil lawsuit if they wanted an eviction.

Squats have been legalized. In Amsterdam, this amounted to about 200 legalizations (Duivenvoorden, 2000, p. 323). The prospect of legalization and the desire to avoid or at least delay eviction involved many squatters in construction planning and in negotiations with municipal officials. Outside the context of legalization, there were many contacts between squatters and state officials as well. In Amsterdam, the municipality offered to make repairs to some of the squats that were slated for eventual demolition, to help keeping the buildings habitable in the meantime, and re-housed displaced squatters in some cases. Subsidized neighborhood centers, along with Church groups, represented squatters' views. In many neighborhoods, for instance Amsterdam's East Docklands, squatters took part in city planning. In various conflicts, politicians mediated. Thus squatting was to some extent institutionalized, and it enjoyed some legitimacy.

The attempted de-institutionalization is visible in the way in which the law appropriates the term 'kraken' (the standard Dutch word for squatting), originally a movement term introduced in 1969 with the establishment of the 'Woningbureau (Housing Bureau) de Kraker' (Van Tijen, 2008), and redefines it into a crime:

'He who unlawfully penetrates an apartment or building, the use of which has been terminated by the person who has the title to it [..] will be punished as guilty of kraken (squatting) with a prison sentence [.... $]^{\prime}$

A puzzling element that needs to be explained, and for which the revanchism approach seems appropriate, is why the political aggression towards squatters culminated three decades after 
the high profile, massive conflicts that involved squatters. In Amsterdam, 1980 was the peak year in terms of major riots related to squatting. The most impact had the events on the Vondelstraat initiated by a re-squatting action on February $29^{\text {th }}$, followed by a clash in which squatters caused the police to retreat. Squatters then built street barricades, which the army and police cleared on March $3^{\text {rd }}$, using tanks equipped with bulldozer blades. This was followed by the riots at the coronation of Queen Beatrix on April $30^{\text {th }}$. These events became part of the Dutch collective memory and, for example, got commemorative media coverage on their 20 and 25 year anniversaries. A third event with a big impact was the eviction of the Lucky Luyk squat on 11 October 1982, especially because of the fact that a tram was derailed and burned. Mak (2000) identifies this as the decisive movement at which squatters lost all support. Outside of Amsterdam, the eviction of squats in the Piersonstraat in Nijmegen on February $23^{\text {th }} 1981$ was the most salient violent confrontation, again involving the use of army tanks. After 1982, non- or relatively less confrontational strands in the movement gained hegemony (Duivenvoorden, 2000). The time lag between the violent episodes that became imprinted in the collective memory and the 2010 anti-squatting legislation supports the interpretation that an element of revenge is present.

After 1982, not much in the way of large-scale conflict happened, and nothing after 2000. After 2000 , there have been complaints by owners of squatted properties, but such complaints had occurred all along since the beginning of squatting. However, after the mid 1990s, squatting in the Netherlands had dwindled to a shadow of what it had been in the 1980s. As an estimate, one can think in the order of ten times smaller.

An important development in terms of curtailing squatting has been the success of the 'antisquatting' industry. This industry consists of companies that supply and manage temporary residents for vacant buildings, who can be told to leave on short notice. Such anti-squatting occupants have few rights, for example in some cases they may not be allowed to have visitors or pets. Large buildings are often only protected by a handful of anti-squatters. Currently, antisquatters can be estimated to outnumber the squatters by ten to one.

Not only was squatting relatively rare in the decade before the 2010 change in the law, but before 2010 owners were already equipped with legal protection against squatters. Since 1994, it was already illegal to squat any building that had been empty for less than one year. Buildings that had been empty for more than one year were protected as well, because owners could expect to obtain swift eviction orders from the courts, provided that they could prove the need for having control over their property reestablished quickly, for example by showing a building permit or demonstrating that they found a tenant. Already in 1981 legislators had made it possible that anonymous squatters could be summoned to court. 
Thus revanchism can explain the long time lag between, on the one hand, the apex of squatting and squatting-related conflict, and on the other hand, the rise of intense anti-squatter political activity.

Lending weight to the interpretation of the 2010 legislation as revenge is the fact that one of the parties that supported the anti-squatter law, the populist PVV of Mr. Geert Wilders, is the party that is most easily associated with revanchism because it positions itself as an anti-Islam party and campaigns against an array of 'left-wing hobbies'. It is also vehemently against squatters. The populists threatened to withhold support for the proposed law against squatting because they felt that the punishment was not harsh enough. They demanded, successfully, that the maximum prison sentences be more than doubled, to a maximum of two years plus eight months. A vocal member of the populist fraction was Mr. Hero Brinkman, who had, from 1985 until 2006, served as a policeman in Amsterdam. There, in the Bellamy neighborhood, his approach toward squatters had earned him the nickname 'Rambo of the Bellamybuurt'. In a talk show he explained that his motivation to go into politics was to put an end to soft policies, for example against squatters. He also said 'gedogen [i.e. pragmatic tolerance] raises my hackles'. ${ }^{2}$

The case of anti-squatting legislation shows, as in Van Eijk's (2010) analysis of urban policy in Rotterdam, that revanchism can have a strong cultural component, and that it is not exclusively bound to the economic logic of gentrification and competition between cities as suggested by Smith (1996, 1998).

\section{Culture wars}

Culture wars are controversies rooted in profound values (Sharp, 1999b). Typically, it involves freedom versus social order (cf. Van der Waal, 2010, p. 210). The metaphor of war suggests that these controversies involve two large groups getting head-to-head. There are various elements in the case that fit this interpretation. First, there is a clear pattern of two large groups getting head to head, since squatting was highly controversial. When Parliament voted on the proposed squatting ban on 15 October 2009, 53 percent was in favor, and 46 per cent against it. For it were all the right-wing parties, including the Christian democrats, against it were all the left-wing parties, including the PvdA, Partij van de Arbeid (social democrats) and D66 (liberal democrats).

Among the Dutch population, squatting was equally controversial. In the survey I asked respondents for their opinion about the statement 'Squatting is fine if he building has been 
vacant for a long time and the owner has no plans for it'. 41.3 percent agreed, 39.2 percent disagreed $(\mathrm{N}=2173)$. $^{3}$

There seems to be stability in the controversy about squatting. In 1980 there were two opinion polls in which the question was asked: 'Now, about the squatting of vacant houses and office buildings: do you find such squatting acceptable or not?'. In the first survey, February 1980, 46 percent found squatting acceptable, 48 per cent did not. In the second survey, April 1980, the percentages were 43 and 52 respectively $(\mathrm{N}=1226 / \mathrm{N}=1195)$ (Nipo, 1980).

The pattern of two large groups getting head to head is also visible in the way in which the legislation was initiated and in the outcome sought by the proponents of the squatting ban. The politicians leading the attack on squatting encountered serious resistance and brought heavy weapons into position. The initiative did not come from the government, which is the more usual way, but from members of parliament. The initiators were Mr. Ten Hoopen of the the Christian democratic party CDA, Mrs. Van den Burg from the liberal conservative party VVD ${ }^{4}$, and Mr. Slob from CU, a small Christian party. Mr. Ten Hoopen had been pushing the idea of a squatting ban for seven years, against the active and passive resistance of a government that was reluctant to make changes regarding the legality of squatting. Already in 2003, Ten Hoopen succeeded in getting a motion passed that asked for a ban on the squatting of commercial buildings. To illustrate the resistance from within the government and the state bureaucracy against a possible ban on squatting: the only thing that happened as result of the passing of the 2003 motion was that the Ministry of Economic Affairs issued a leaflet warning owners of commercial property not to leave their property empty. This official publication concluded with the statement: 'Squatters can cause trouble and damage. Therefore, property owners sometimes wonder why squatting is still allowed in some cases. The Netherlands is a small country with many inhabitants. For this reason, we have to use available space carefully. Vacancy has to be avoided' (Ministerie van Economische Zaken, 2004). Introducing a prison sentence can be seen as wielding a heavy weapon against squatters, because prison sentences are normally only attached to types of acts that are widely rejected, not to highly controversial issues.

That the conflict was to a great extent about values shows in various ways. In the debates, proponents of the squatting ban generally took recourse to the norm of private property as an absolute principle. An example can be seen in the following interaction that took place during a meeting between a group of squatters and member of parliament Mr. Slob of the Christian party CU, set up at the request of a squatter who was a member of this party himself. The key issue was the possible contradiction between Christian ethics and a ban on squatting. Squatters from the towns of Deventer and Etten-Leur explained how they were taking care of homeless 
people, and expressed their disappointment about how a fellow Christian could criminalize what they were doing. Mr. Slob replied that he deemed such projects 'very valuable initiatives'. A young woman told Slob that she had run away from home at the age of fourteen, and that the official institutions in the field of youth care had been unable to help, and that squatters had given her a home and had cared for her. Mr. Slob replied that he had nothing to detract from the accounts presented to him, but that he was following the party line that squatting was 'not legitimate', and that the new law would make it easier to track down and apprehend 'diehards'.

The squatters' reactions to the proposed anti-squatting law also fit the picture of a culture war. Squatters mounted various national campaigns to reach out to the section of the public that could be counted on as being open-minded. There were open days on which squats across the country welcomed visitors. Activists organized city walking tours to show local squatting history. Cultural institutions, especially pop music venues that had their roots in squatting, were asked to put out a banner proclaiming that the squatters' movement had helped to make it possible. Squatters put together a book documenting positive cases of squatting (Kaulingfreks et al., 2010), launched it with fanfare in a squatted social center, and brought it to the attention of politicians. There was coalition-building with tenants under the label 'Woonstrijd' ('housing struggle') and with groups of urban renewal/gentrification victims (Nieuw Crooswijk, Rotterdam). As a non alienating protest, activists squatted an empty villa around the corner from Housing Minster Dekker's home in Wassenaar, one of the richest communities in the Netherlands. In this action, the squatters practiced reverse gentrification, and explained that by doing this, they helped fulfill the minister's aim to 'improve social cohesion' by mixing people of different income groups. Housing minister Dekker came over to the new squatter neighbors to discuss her policy. Posing as 'real estate people', squatters demonstrated in the posh P.C. Hooftstraat in Amsterdam, demanding an anti-squatting law.

The squatters' campaigns found considerable resonance. Cultural figureheads and politicians spoke out against a ban on squatting. This included social democratic politicians, which was fairly unprecedented and different from the late 1970s and early 1980s, when the social democrats had been in the camp of squatting ban supporters. Together with the Christian democrats, they created the 1981 Leegstandswet (vacancy law), aimed to fight squatting and to legitimize this by simultaneously regulating vacancy ${ }^{5}$. It introduced rules that enabled cities to requisition empty buildings. Cities were to set up registers of vacant buildings, and the law made squatting a registered building a criminal offense (Salomons, 1982). The vacancy register never materialized however, and by implication the law missed the objective of imposing a ban on squatting. 
When the issue of a squatting ban reemerged in 2003, social democratic politicians and others on the left side of the political spectrum tended to be against the proposed ban on squatting. A contributing factor in the widespread support for squatting is the fact that a gradual erosion of squatters' rights that happened in the decades before had created a legal situation which politicians felt they could defend. Sustained squatting was only possible in buildings that had been empty for more than one year, and for which the owner had no immediate, feasible plan. Judges decided on a case by case basis whether the owner's claim for a pressing need for swift eviction was grounded. For example, Amsterdam's alderman Maarten van Poelgeest of the green party Groenlinks defended the pre-squatting ban status quo as one characterized by a balance of interest. ${ }^{6}$

The culture wars perspective alerts us to the possibility that an obvious manifestation of a decline of tolerant public policy, such as sharply increased criminalization, does not necessarily mean that society at large has become much less tolerant. There can still exist a very large protolerance section, in which there is also positive support for certain actions that others see as deviant.

The case of squatting suggests that institutionalization plays a role in a culture war. The arrangement prior to the squatting ban was a form of institutionalization that regulated conflict. This limited the opportunities for squatting but broadened support at the same time. It also shows that a cultural war can run a long time, in slight contrast to the idea that it is a manifestation of a new political culture (Clark 1998). In the case of squatting, the newness is relative. Political efforts to stamp out squatting have been under way since 1971. In 1975, justice minister Van Agt, when answering questions from parliament members, made it clear that his proposed anti-squatting law had mainly a 'norm-reaffirming' purpose. And in the 1980s, the stated motive for the above-mentioned 'Leegstandswet' (vacancy law) initiative towards banning squatting was that the legal order ('rechtsorde') was at stake.

\section{Moral panic}

The concept of moral panic denotes a mechanism that entails the construction of a social orderthreatening reality in the media. Squatting is susceptible to this. This does not so much pertain to the core of squatting itself, the opening up of a building by people who turn it into their home, or who use it to organize social activities. It is eviction-related incidents that involve violence, of allude to it, that can trigger a moral panic. Exaggeration, labeling and stigmatization are features of this process (Amann, 1985). 
The history of the efforts to create anti-squatting legislation is complicated ${ }^{7}$, but the bottom line is: since the beginning of squatting in 1965 there has always been a majority in Parliament and Senate prepared to make laws against squatting. A crucial element, however, is agenda setting. This is exactly where a moral panic can make a difference. In this case, a moral panic made the lingering issue of a squatting ban more salient and it imparted a sense of urgency. In what we could see as a lingering phase, between 2003 and 2007, Christian democratic member of Parliament Jan Ten Hoopen, followed by some of his colleagues, submitted several motions asking for a squatting ban, which were accepted by Parliament, but not greeted with much enthusiasm by the government. In 2006, the ministers for Housing and for Justice replied that they were planning to prepare a proposal to make squatting punishable regardless of how long the building had been vacant, but they added that property owners had a responsibility not to let their buildings stand vacant. They also announced that the Department of Justice would issue instructions to public prosecutors on how to decide whether prosecution would be opportune. Prosecutors were to take factors such as the effort that the owner had made to prevent squatting and the duration of the vacancy into account. This amounted to making squatting illegal while keeping the status quo largely intact.

The lingering phase was followed by a phase characterized by increased salience of the issue and a sense of urgency, and in which the anti-squatting law became reality, 39 years after its first mention in parliamentary discourse. This transition seems caused by a moral panic. In 2007, there were two incidents in Amsterdam in which the police reported that squatters had left booby traps in barricaded squats. In the first case the police said that a part of the roof had been rigged to fall down on police officers, in the second case that a gasoline-filled jerry can had been placed behind a steel plate with the idea that an explosion or fire would result when officers would cut through it with an angle grinder. Statements from within the squatter scene contradict this. Common in all the different accounts is, that the squatters barricaded the houses in such a way that they could leave while the police still would have difficulties getting in. This strategy left the power of interpretation entirely in the hands of the police.

After these incidents, police chiefs appeared in the media voicing concerns over the safety of their men. Prime Minister Balkenende declared being shocked, Jan ten Hoopen announced that he would submit an initiative for an anti-squatting law. ${ }^{8}$ In 2008, the impression of a violent turn in the Amsterdam squatters' movement was reinforced by a case in which the Amsterdam police reported to have found various weapons during an eviction. ${ }^{9}$

The initiators of the anti-squatting law that was passed in 2010 wrote in the explanatory text that went with their proposal: 
'Recent incidents, such as the eviction in Amsterdam in May 2008, that involved violence and in which 51 squatters were arrested and a variety of weapons were found, are the direct impetus for this proposal for a new law.'

This seems a classic case of a moral panic. It unfroze a culture war in which the conservative side, driven partly by revanchist emotions, had a slight upper edge.

\section{Creative Cities}

The mechanisms described under the headings 'revanchism' and 'moral panics' entail a decline of tolerance. If only to avoid a negative bias, we also need to consider possible mechanisms that can cause an increase or stabilization of tolerance. The creative cities literature posits such a mechanism, because it sees tolerance is an important characteristic of post-industrial cities, and as one that would be rational to nurture, because it constitutes a competitive advantage (Florida, 2002).

Indeed, stabilization of tolerance was the pattern seen in the official reactions from the big cities. The administrations of the four largest cities, Amsterdam, Rotterdam, the Hague and Utrecht made it clear that they did not support the proposal. The VNG (Vereniging van Nederlandse Gemeenten), the association of all Dutch municipalities, was internally divided on the issue, although it externally announced its disapproval of the proposal. The internal division became apparent when VNG representative Mr. S. Van der Tak, mayor of the Municipality of Westland, a combination of small towns, was heard by the Permanent Justice Committee of Parliament. During this hearing, he repeatedly dissociated himself from the VNG standpoint he was supposed to be representing, saying that many small towns' administrations in fact supported the anti-squatting proposal.

The division between big cities and small towns was used by Mrs. Van der Burg, one of the three authors of the proposal, in an attempt to sway the position of the VNG. Reportedly, she specifically lobbied right-wing Christian democrat politicians in small towns, who could be expected to be pivotal. This observation was made by a squatter who enrolled herself, posing as a member of the liberal conservative VVD, on the social networking site Hyves to get an inside view on anti-squatting politics. She joined a group of young VVD members that was mobilized by Van der Burg through the website to go to the hearing in Parliament collectively, and was present when Van der Burg explained her strategy to the group.

The division also comes to light in Van Boxtel's (2010) report on a poll about the squatting ban among municipalities larger than 100.000 inhabitants. Representatives of these municipal 
administrations were asked how they felt about the law and whether they would want to make use of it. Rejection of the proposal was general among the large cities, while the smaller cities tended to be more positive.

Finally, it seems that among the general public in large cities there tends to be more support for squatting than in small towns and villages. In the above-mentioned survey, I tried to measure the respondents' support for the idea of squatting by asking their opinion about the statements 'owners of houses should be able to determine for themselves whether they let their buildings or leave them vacant', 'squatting is fine if the building has been vacant for a long time and the owner has no plans for it' and 'squatting a vacant building should always be forbidden'. The reliability of this scale is acceptable, since Cronbach's Alpha is 0,712 . The dataset includes an indicator for the level of urbanity of the respondent's place of residence. This made it possible to see whether there was any relation between urbanity and support for the idea of squatting. There is a fairly slight positive statistically significant relationship (the Pearson correlation is $0,182 * * 10, N=2026)$.

The two-edged sword of creative city

In the Netherlands, Amsterdam is probably the most extreme creative city. It is a preferred place for the creative class and attracts media companies, head offices of financial companies and other companies that want to be in touch with the hip scene, such as Philips. Florida (2008, p. 157) mentions Amsterdam as one of the world's most open and relatively prejudice-free cities, and one of the most attractive places in the world for young graduates. Nijman (1999, $p$. 154) points to a centuries-old tradition of tolerance for diversity, and also notes that since the 1960s, Amsterdam is the 'anti-establishment city' of the country. The anti-establishment tradition, that Amsterdam shares with Nijmegen, attracts students and other young people who are interested in radical politics. In Amsterdam, Florida's message that tolerance, together with talent and technology are key to a city's success strongly resonated with policy makers (Peck, 2011).

Indeed, the revanchist offensive and the moral panic seemed to have little effect in Amsterdam. It was not more than an undercurrent, expressed for example by a liberal conservative council member who published an anti-squatting report and campaigned for a squatting ban (Van 't Wout, 2008).

The statistics bureau of the city of Amsterdam did a poll on the squatting ban, asking 'All arguments considered, are you in favor or against the prohibition of squatting?' and concluded that the citizens of Amsterdam tended to be against the ban. Only 20 percent of respondents 
fully supported a prohibition of squatting, 42 per cent were fully against it $(N=500)$ (Gemeente Amsterdam, 2008).

Van Boxtel (2010) reports that the municipal authorities of Amsterdam deemed the proposed law 'counterproductive, because it will lead to more vacant buildings'. Some of the most outspoken prominent opponents of the law were from Amsterdam. Alderman Herrema credited the squatters' movement for saving neighborhoods that had been slated for razing and that were now thriving, while distancing himself from violence and the occasional thrashing of buildings brought to his attention by owners who had come to his office 'crying in despair'. He also praised squatters for cultural initiatives and for being the only people who had proved to be able to keep track of vacant buildings, something city officials had been unable to do. Alderman Van Poelgeest expressed frustration by the fact that within Amsterdam's borders there was one million square meters of empty office space, and that he did not have the instruments that would enable him to handle this problem. He said that the best solution would be that these buildings were squatted. Amsterdam's mayor Cohen dealt with squatting incidents on a case-by-case basis, while sticking to the viewpoint that a general ban on squatting was unwanted. These leading Amsterdam politicians supported the squatters, even though the origin of the moral panic was in their city. This implies that, had Amsterdam's response been representative for the political system as a whole, there would be been no squatting ban.

There is great diversity in squatting (Pruijt, 2012) and most types existed in Amsterdam. Entrepreneurial squatters who created artists' workspaces and venues for cultural activities were seen by policy makers as valuable for the city, which led to connections between the squatter scenes and the local administration. For example, in 1998 users of squatted living / working / culture buildings made an appeal to the City Council because they felt threatened in their existence, and that prompted the start of the 41 million euro municipal 'Breeding Places Amsterdam' (BPA) project in 1999 (Pruijt, 2004). In contrast, squatters who just housed themself provoked less enthusiasm, and squatters who fought against gentrification in the shape of selling affordable rental apartments got a mixed reception. Liberal democratic council member Capel, for example, strongly supported cultural entrepreneurial squatters while condemning squatters who tried to block gentrification in the form of the sale of rental apartments.

Alderman Herrema was influential in the VNG, the association of Dutch municipalities. Thus, by involving local politicians, the dynamic of the creative city helped broaden the pro-squatting side in the cultural war. 
However, conceivably, the creative city dynamic also contributed to the events that led to the moral panic. Amsterdam has a protest-friendly climate, in the sense that there is little risk that a backfiring protest leads to repression by the local authorities. Squatting-related protest tends to take the following shape. In Amsterdam, there is a long-standing tradition that the police make about three 'eviction rounds' per year, evicting all squats that have pending eviction notices. In many cases, squatters simply walk away from their squats before the police arrive, but some squats are symbolically defended or left barricaded. This is in contrast to, for example, Rotterdam, where squatters normally abandon their building voluntarily in case of an eviction notice.

The 'booby trap' incidents can be seen as exceptions in a series of protests, exceptions because they backfired. The cost of this backfiring protest to the Amsterdam squatters' movement did not seem very high, because the authorities chose communication as a preferred solution rather than repression. Squatters in Amsterdam were shocked by the accusations about booby traps, and radiated disbelief. Explanations could be heard that in the first case, the roof had been in such a bad condition that it had to be propped up, and that an object had been rigged to fall on a fire extinguisher with the idea that it would go off when the police approached. In the second case, in which the police reported to have found gasoline placed in such a way as to present a danger to them, squatters said that perhaps it had been left by builders. The squatters' reactions of disbelief signal a normative communality with the authorities, i.e. that endangering police personnel was not acceptable. In a City Council committee meeting that was partly devoted to the incidents, squatters were present, and four of them had registered themselves to get the opportunity speak. After police commissioner Schönfeld showed photos, council members of all parties expressed disapproval with the squatters' actions as presented by the police. A councilwoman of the green party GroenLinks made an appeal to the 'selfcleaning power' of the squatters' movement, quoting a similar appeal made earlier that year by police commissioner Schönfeld (Rombouts, 2007). Some of the squatters told the politicians that they did not believe the account presented by the police, but added that they personally had not been present. The mayor warned that, if there would be any more incidents like this, evictions could be undertaken without telling the squatters in advance. Finally, the mayor asked each of the four squatters individually whether 'it was really necessary to create such a mess'. The squatters replied that they personally would not have acted in this way. ${ }^{11}$

In 2009, I asked police commissioner Mr. L. Schaap, the commander of the unit that carries out evictions of squats, about the situation in Amsterdam, referring to the earlier commotions about reported booby traps. This was at the occasion in which the positive book on squatting (Kaulingfreks et al. 2009) was presented to the public in the squatted social center 'De Illusie' in The Hague. Mr. Schaap assessed the situation in Amsterdam as 'completely normalized'. 
In a discussion after the events, the strategy of defending buildings and staging protest at evictions was seen by some of the Amsterdam squatters as advantageous, because 'otherwise one is not taken seriously' and it is a way to 'get the story across', which is often a story of an owner engaged in speculation and of mistreatment of tenants. Emotional reasons were also mentioned, that it is good to protest at the eviction of, for example, a social center in which one had invested much energy.

In Amsterdam, housing conflict is relatively intense, compared to for example Rotterdam, Utrecht and the Hague, because of the fact that the scale of organized squatting is much larger, the very strong demand for affordable housing, the existence of controversial policies to turn affordable rentals into apartments that can be sold and the prevalence of more or less criminal real estate speculation. Thus in Amsterdam there were clear reasons for protest at evictions, while the cost of protest was low even when it backfired. This was because the authorities thought that squatters would manage to avoid it in the future, which turned out to be realistic. The moral panic caused just a ripple in Amsterdam, but it triggered a major backlash on the national level that affects squatters outside the successful postindustrial city and the long-term prospects for squatting in the Netherlands. ${ }^{12}$

\section{Conclusion and discussion}

The case of a decline of tolerant public policy analyzed in this paper, anti-squatter legislation in the Netherlands, highlights the value of combining several perspectives. The concept of Revanchism, a reaction against a perceived lack of order caused by leftist sixties-style tolerance (Smith, 1996, pp. 44-45), offers an explanation for the long time lag between the peak of squatting and the decisive political moves to make squatting illegal. Revanchism does not explain the precise timing. The concept of the moral panic, a scenario in which incidents enable the construction of a menacing reality in the media, prompting political interventions in the direction of increased repression (Hall et al., 1978; McRobbie and Thornton, 1995), neatly captures the mechanism that seems at work. The evictions in Amsterdam in which the police reported the existence of booby traps turned a relatively simmering issue into a salient one.

The focus in the discourse on values, and the fact that this issue divided the public, and split the political landscape, into two big sections fits in the trend outlined in the culture wars literature, that the main fault lines are shifting from the economic to the cultural dimension (Sharp, 1999). For those wishing to put an end to the tolerance for something, engaging in a culture war allows them to inject some value rationality into their discourse, which would otherwise be dominated by revanchist emotions and moral panic-related exaggeration. Adversaries can 
easily puncture such emotional and exaggerated discourse. The latter occurred in the case of the anti-squatter legislation in the campaigns mounted by squatters to defend the status quo. They presented squatting projects that showed how squatters created housing and spaces for social and cultural activities. The campaigns also highlighted the role of squatting in the development of the nation's cultural infrastructure.

Thus, revanchism supplied aggression to a battle in a protracted culture war, which was unfrozen from a lingering state by a moral panic. That this moral panic was triggered by events that occurred in Amsterdam, while squatting in the Netherlands is nationwide, is probably not a coincidence. In Amsterdam real estate speculation and the conversion of rentals into condominiums gave rise to protest at evictions, but Amsterdam is a also an extreme case of a creative city, which entails a tolerant climate. In such a city, there is little reason for activists to fear the costs incurred when a protest backfires, because the authorities prefer to exert control by communication rather than by repressive measures. If, however, revanchist cultural warriors find a lever on the national level that they can use, the dynamic of the creative city can turn out to be a two-edged sword.

What the argument presented above did not fully encompass is the theoretical possibility that the loss of tolerance was not caused by political change but by changes in the nature of squatting itself. Indeed, the motivation for the proposal for the anti-squatting law states that several changes made it necessary. The initiators claim that squatting had become less related to housing shortage and less directed against the problem of vacancy, but increasingly about easy and cheap living on attractive locations. However it is doubtful that such a pattern became more prevalent because recent squatting, especially in Amsterdam, often entails protest against real estate speculation and conversion of social housing into apartments to be sold on the market. Moreover, in the recent years squats tend to last only a few months. The possibility to live easy in a squat is much more something of the 1980s, when life spans of squats were measured in years. A further incorrect claim in the motivation for the proposal is that the movement had become more violent-prone. In reality, the movement had, over time, become 'pacified', according to assessments made by squatters and by law enforcement officials in Amsterdam (Van Gemert et al. 2009, p. 58).

A more substantiated claim in the motivation is that increasingly, non-Dutch citizens, including touristic' squatters from South and East Europe, were among the active squatters. The example given is a 2007 eviction at which individuals representing nine different foreign, but Western, nationalities were arrested. The conclusion attached was that Dutch policy should avoid attracting foreign squatters. It is true that squatting has internationalized. Van Gemers et al. (2009) estimate, in correspondence with police data, that about a third of the squatters in 
Amsterdam were foreign. Foreign squatters, because of their lack of roots in Dutch society, can easily be treated as undesirables that should and can be removed and prevented from coming; their presence facilitated the construction of revanchist discourse.

Thus, political change in the shape of revanchism, against the background of cultural war, is an important factor in the explanation for the fact that the squatting ban emerged long after the apex of the squatters' movement and after its pacification. This does not suggest that the role of activists has to passive. Space for activist agency exists in coalition building in the cultural war. Moral panic risk management also seems crucial, but it is a complicated proposition because the political systems of the creative city and the country as a whole react differently.

\section{References}

Amann, R. (1985) Der moralische Aufschrei. Presse und abweichendes Verhalten am Beispiel der Hausbesetzungen in Berlin. Frankfurt/Main: Campus Verlag.

Bannister, J., and Kearns, A. (2009) Tolerance, Respect and Civility Amidst Changing Cities, in Millie, A. (ed) Securing Respect: behavioural expectation and anti-social behaviour in the UK. Bristol, Policy Press, pp. 171-191.

Boxtel, H. van (2010) Kraakverbod onbruikbaar. Binnenlands Bestuur, 30, May 28, pp. 62-65, retrieved on 3-01-2012 from http://www.binnenlandsbestuur.nl/ruimte-enmilieu/achtergrond/achtergrond/kraakverbod-onbruikbaar.170780.lynkx.

Clark, T. N. (ed) (1998) The New Political Culture. Boulder: Westview Press.

Davis, M. (1990) City of Quartz. Excavating the Future in Los Angeles. New York: Vintage Books. Duivenvoorden, E. (2000) Een Voet Tussen de Deur. Geschiedenis van de Kraakbeweging 19641999. Amsterdam: Arbeiderspers.

Florida, R. (2002) The rise of the creative class. And how it's transforming work, leisure, community and everyday life. New York: Basic Books.

Florida, R. (2008) Who's your city? New York: Basic Books. 
Gemeente Amsterdam, Dienst Onderzoek en Statistiek (2008) Amsterdammers tegen kraakverbod, 29-8-2008, retrieved on July 8, 2010, from http://www.os.amsterdam.nl/nieuws/10377.

Gordijn B. (2001) Regulating moral dissent in an open society. The Dutch experience with pragmatic tolerance. Journal of Medicine and Philosophy, 26, 3, 225-244.

Hall, S., Critcher, C., Jefferson, T., Clarke, J. and Roberts, B. (1978) Policing The Crisis - Mugging, The State, And Law And Order. New York: Holmes and Meier Publishers.

Kaulingfreks, F., Combrink, T., Schrauwen, I., Egas, G., Cafard, J., Rensen, P., Wieland, J. W., Van Ouwerkerk, M., Schmidt, D., Hallegraeff, G., Oudenampsen, M., Feith, V., Van der Velden, L., Rosinga, B. and Bouwknecht, P. (2009) Witboek Kraken. Krakend Nederland Presenteert: 132 Bladzijden met Meer Dan 80 Kraakpanden in 20 Steden. Breda: De Papieren Tijger.

Kearns, A., and Bannister, J. (2009) Conceptualising Tolerance: Paradoxes of tolerance and intolerance in contemporary Britain. Italian Journal of Sociology of Education, 2, 126-147.

Mak, G. (2000). Romantiek van baksteen. Geschiedenissen van de 'stadsoorlog. NRC Handelsblad. Rotterdam: Katern Boeken, 28-4-2000, 1.

Maussen, M. and T. Bogers (2010) Tolerance and Cultural Diversity Discourses in the Netherlands. San Domenico di Fiesole, European University Institute, Robert Schuman Centre for Advanced Studies, http://www.eui.eu/Projects/ACCEPT/Documents/Research/wp1/ACCEPTPLURALISMWp1Backgr oundreportNetherlands.pdf, retrieved on 18-12-2011

McRobbie, A. and Thornton, S. L. (1995) Rethinking 'Moral Panic' for Multi-Mediated Social Worlds. The British Journal of Sociology, 46, 4. pp. 559-574.

Ministerie van Economische Zaken (2004) Hoe om te gaan met kraken, Den Haag, Ministerie van Economische Zaken, www.rijksoverheid.nl/documenten-enpublicaties/brochures/2009/10/28/hoe-om-te-gaan-met-kraken.html, retrieved on 13-5-2011.

Nijman, J. (1999) Cultural globalization and the identity of place: the reconstruction of Amsterdam. Cultural Geographies, 6, 2, pp. 146-164.

NIPO (1980) Bericht no.: 2055, 8 July, Amsterdam: Het Nederlands Instituut voor de Publieke Opinie en het Marktonderzoek B.V. 
Peck, J. (2011) Recreative City: Amsterdam, Vehicular Ideas and the Adaptive Spaces of Creativity Policy. International Journal of Urban and Regional Research. Article first published online: DOI: 10.1111/j.1468-2427.2011.01071.x

Peck, J., and Tickell, A. (2002) Neoliberalizing Space. Antipode 34, 3, pp. 380-404.

Pruijt, H. (2004) Squatters in the Creative City: Rejoinder to Justus Uitermark. International Journal of Urban and Regional Research 28,3. pp. 699-705.

Pruijt, H. (2012) The Logic of Urban Squatting. International Journal of Urban and Regional Research. Article first published online: DOI: 10.1111/j.1468-2427.2012.01116.x.

Rombouts, R. (2007) Een boobytrap, dat gaat te ver; jerrycans hadden bij ontruiming in de fik kunnen gaan, Het Parool, Amsterdam (p. 99, Section: Amsterdam, March 28).

Salomons, E.H.C. (1982) Beleid rond de Leegstandwet in: Kleyn, W. M. et al. Leegstandbestrijding: de Leegstandwet, tijdelijke verhuur, vorderen en kraken, Alphen aan den Rijn: Samsom/H.D. Tjeenk Willink, pp. 60-68.

Sharp, E. B. (ed) (1999a) Culture wars and local politics. Laurence: University Press of Kansas.

Sharp, E. B. (1999b) 'Introduction', in Sharp, E. B. (ed) Culture wars and local politics. Laurence: University Press of Kansas, pp. 1-20.

Smith, N. (1996) The new urban frontier. Gentrification and the revanchist city. London and New York: Routledge.

Smith, N. (1998) Giuliani Time: The Revanchist 1990s. Social Text, 16,4, pp. 1-20.

Soja, E. (2000) 'The stimulus of a little confusion. A contemporary comparison of Amsterdam and Los Angeles', in Deben, L., Heinemeijer, W., and Van der Vaart, D. (eds) Understanding Amsterdam. Essays on economic vitality, city life and urban form. Amsterdam: Het Spinhuis, pp. 117-141.

Tijen, T. van (2008) Zwartmakers en een pleidooi voor een 'Witboek Kraken', imaginarymuseum.org/LimpingMessenger/WitboekKraken2008.html, accessed on May 23-52011.

Waal, J. van der (2010) Unraveling the Global City Debate. Economic Inequality and Ethnocentrism in Contemporary Dutch Cities, Rotterdam. PhD Thesis Erasmus University Rotterdam. 
Van Eijk, G. (2010) Exclusionary Policies Are Not Just About the neoliberal City: A Critique of Theories of Urban Revanchism and the Case of Rotterdam. International Journal of Urban and Regional Research 34, 4, pp. 820-834.

Van Gemert, F., Siegel ,D., Visser, R., Dadusc, D., and C. Brouwers (2009) Kraken in Amsterdam anno 2009. Amsterdam: Sectie Criminologie, Vrije Universiteit Amsterdam.

Van Noort, W. (1988) Bevlogen bewegingen. Een vergelijking van de anti-kernenergie, kraak-en milieubeweging. Amsterdam: SUA.

Wout, B. van 't (2008) Zwartboek Kraken. Amsterdam: VVD.

Yin, K. (2009) Case Study Research. Design and Methods. Fourth Edition. Los Angeles: Sage.

Zahn, E. (1993) Das unbekannte Holland. Regenten, Rebellen und Reformatoren. München: Goldmann.

\footnotetext{
${ }^{1}$ I inserted three questions on squatting in an online questionnaire for the CentERpanel of CentERdata, as part of the project Arbeid, Bedrijf en Sociale Zekerheid in Nederland 2006. The CentERpanel is an appropriate representation of the Dutch-speaking population.

${ }^{2}$ Pauw \& Witteman, Vara, 11-04-2008, http://player.omroep.nl/?aflID=6835909

${ }^{3}$ Van Noort (1988) writes that, because of a violent turn in the early 1980s, squatters lost all sympathy. The survey results, and the political opposition against the proposal, contradict this; perhaps the effect of the riots from the early 1980s was short-lived.

${ }^{4}$ The Dutch conservatives, i.e. the VVD, call themselves 'liberals'.

${ }^{5}$ The justice minister clearly explained this in his reply to Raad van State (the Dutch government's advisory body on legislation matters), 10 July 1980.

${ }^{6}$ He said that he liked the legal practice that had developed, in which a judge balances the interest of the owner and the interest of society. He added that letting a judge decide was a good way to handle the clash of two basic rights. This was at one the liberal conservative party VVD's 'political café's', to which he had been invited to receive the first copy of a publication containing stories told by owners whose properties had been squatted (van 't Wout 2008).

${ }^{7}$ Since 1978, all initiatives to stamp out squatting include proposed policies to tackle the problem of empty buildings. The complications caused by this are largely ignored in this paper.
} 
${ }^{8}$ In the lingering phase, politicians who where pushing for a squatting ban tried to substantiate the urgency by referring to illegal house parties that took place in commercial buildings occupied for the purpose, without offering specific examples, and by claiming that squatting bans in other countries pushed foreign squatters towards the Netherlands.

${ }^{9}$ This involved knives, bats or clubs, a 'gas pistol', a 'shooting pen', and a few pieces of ammunition of various calibers but no gun.

${ }^{10}$ Correlation is significant at the 0.01 level (2-tailed).

${ }^{11}$ Commissie Algemene Zaken, 08-11-2007, http://amsterdam.raadsinformatie.nl/uitzendinggemist.php?ag=63\#.

${ }^{12}$ The city councils of Amsterdam and Utrecht have, after the senate passed the law, voted in favor of motions to disregard it. 